Table 1. Multivariate logistic regression of variables associated with initiation of bDMARDs.

\begin{tabular}{|c|c|c|c|c|c|c|c|}
\hline & & $B$ & S.E. & Wald & OR & $95 \% \mathrm{Cl}$ & $p$ \\
\hline \multirow[t]{2}{*}{ Worker type ${ }^{a}$} & Non-hard & & & & ref. & & \\
\hline & Hard & 1,127 &, 509 & 4,890 & 3.09 & $1.14-8.37$ & $.027^{\star}$ \\
\hline \multirow[t]{2}{*}{ HLA-B27 } & Negative & & & & ref. & & \\
\hline & Positive & 1,153 & ,670 & 2,962 & 3.17 & $0.85-11.77$ & .085 \\
\hline \multirow[t]{2}{*}{$\mathrm{CRP}^{a}$} & Normal & & & & ref. & & \\
\hline & $\begin{array}{c}\text { Elevated } \\
\leq 2\end{array}$ & 1,003 &, 529 & 3,591 & $\begin{array}{l}2.73 \\
\text { ref. }\end{array}$ & $0.97-7.69$ & .058 \\
\hline Grade of Sacroiliitis $^{a}$ & $>2$ & 1,485 & ,489 & 9,226 & 4.41 & $1.69-11.50$ & $.002^{*}$ \\
\hline History of Enthesitis ${ }^{a}$ & Yes & ,299 &, 574 & ,272 & 1.35 & $0.44-4.15$ & .602 \\
\hline
\end{tabular}

${ }^{a}$ At the time of diagnosis; ref. - referenceS.E. - Standard Error; OR - Odds Ratio; $\mathrm{Cl}$ Confidence Interval

Conclusion: In our study, the performance of work associated with greater biomechanical stress and the presence of greater structural damage at diagnosis were shown to be associated with the latter use of bDMARDs. The authors highlight the importance of recognizing these factors that seem to relate to more aggressive disease, with more structural damage, thus suggesting a need for a tighter control management strategy in these patients accordingly current guidelines. More studies still needed to better depict the influence of certain early clinical and patient related variables in management of axSpA patients.

REFERENCES:

[1] Png WY, Kwan YH, Lee YX, et al. Factors Associated with Initiation of Biologics in Patients With Axial Spondyloarthritis in an Urban Asian City: A PRESPOND Study. J Clin Rheumatol. 2019 Mar;25(2):59-64.

[2] Inman R, Garrido-Cumbrera M, Chan J, et al SAT0629-HPR FACTORS ASSOCIATED WITH USE OF BIOLOGICAL THERAPIES FOR AXIAL SPONDYLOARTHRITIS IN CANADA. RESULTS FROM THE IMAS SURVEY. Annals of the Rheumatic Diseases 2020;79:1274-1275.

Disclosure of Interests: None declared

DOI: 10.1136/annrheumdis-2021-eular.2952

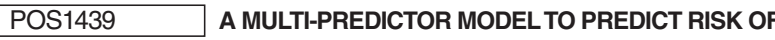 SCLERODERMA RENAL CRISIS IN SYSTEMIC SCLEROSIS}

D. $\mathrm{Xu}^{1}$, R. Mu ${ }^{1} .{ }^{1}$ Peking University Third Hopsital, Department of Rheumatology and Immunology, Beijing, China

Background: Scleroderma renal crisis (SRC) is a life-threatening syndrome. The early identification of patients at risk is essential for timely treatment to improve the outcome $e^{[1]}$

Objectives: We aimed to provide a personalized tool to predict risk of SRC in systemic sclerosis (SSc).

Methods: We tried to set up a SRC prediction model based on the PKUPH-SSc cohort of 302 SSc patients. The least absolute shrinkage and selection operator (Lasso) regression was used to optimize disease features. Multivariable logistic regression analysis was applied to build a SRC prediction model incorporating the features of SSc selected in the Lasso regression. Then, a multi-predictor nomogram combining clinical characteristics was constructed and evaluated by discrimination and calibration.

Results: A multi-predictor nomogram for evaluating the risk of SRC was successfully developed. In the nomogram, four easily available predictors were contained including disease duration $<2$ years, cardiac involvement, anemia and corticosteroid $>15 \mathrm{mg} / \mathrm{d}$ exposure. The nomogram displayed good discrimination with an area under the curve (AUC) of $0.843(95 \% \mathrm{Cl}: 0.797-0.882)$ and good calibration. Conclusion: The multi-predictor nomogram for SRC could be reliably and conveniently used to predict the individual risk of SRC in SSc patients, and be a step towards more personalized medicine.

REFERENCES:

[1]Woodworth TG, Suliman YA, Li W, Furst DE, Clements P (2016) Scleroderma renal

crisis and renal involvement in systemic sclerosis. Nat Rev Nephrol 12 (11):678-91. Disclosure of Interests: None declared

DOI: 10.1136/annrheumdis-2021-eular.3613

\section{POS1440 ASSOCIATION BETWEEN SERUM URATE AND INFLAMMATORY MARKERS IN YOUNG ADULTS: CROSS SECTIONAL FINDINGS FROM A BIRTH COHORT}

T. Loyola Correa ${ }^{1}$, I. Oliveira de Oliveira ${ }^{2} .{ }^{1}$ Universidade Federal de Pelotas, Faculty of Medicine, Pelotas, Brazil; ${ }^{2}$ Universidade Federal de Pelotas, Postgraduate Program in Epidemiology, Pelotas, Brazil
Background: Uric acid is the end product of purine metabolism and an abruptly increase or decrease on its serum concentrations can form free urate crystals and precipitate a gout attack. Serum urate (SU) has been positively and independently associated with cardiometabolic diseases in observational studies, but causal roles remain unclear. $^{1}$ In addition inflammatory markers are deeply associated with cardiometabolic diseases, such as essential hypertension and type 2 diabetes mellitus. ${ }^{2}$ How ever, little has been published about the association of SU and subclinical inflammation.

Objectives: To assess the associations of SU with interleukin 6 (IL-6), C-reactive protein (CRP), and adiponectin at 22-year-old individuals belonging to the 1993 birth cohort of Pelotas (Brazil).

Methods: During 1993, all live born babies in the city were invited to take part in a prospective study and sub-samples of this cohort were followed-up since then. At the 22-year follow-up, interviews and clinical measurements were performed and non-fasting blood samples were drawn from the participants SU was evaluated by enzymatic-colorimetric assay; IL- 6 and adiponectin, by immunoassay; and CRP by immunoturbidimetric assay. The co-variables taken into consideration were skin color; asset index at 22 years; cardiometabolic risk factors (body mass index, systolic and diastolic blood pressure); presence of cardiometabolic diseases (hypertension, diabetes and dyslipidemia); and behavioral variables (alcohol use disorder, smoking status and physical inactivity). Exposition variables were categorized into tertiles. Sex-stratified linea regressions have been performed using STATA 13 and $p<0.05$ was considered statistically significant.

Results: The sample was composed by 1657 (46.3\%) men and 1921 (53.7\%) women of 22 years old. The median (25-75 IQR) for IL-6 (pg/mL) was highe in women than in men $[1.26(0.85 ; 2.02)$ vs. $1.07(0.76 ; 1.69)]$; the same was observed for CRP $(\mathrm{mg} / \mathrm{dL})[1.6(0.6 ; 4.1)$ vs. $0.6(0.3 ; 1.4)]$. The mean $(95 \% \mathrm{Cl})$ for adiponectin $(\mu \mathrm{g} / \mathrm{mL})$ was also higher in women $[10.72(10.50$ $10.94)$ vs. $7.97(7.78 ; 8.16)]$. As expected, the mean $( \pm S D)$ for $S U(m g / d L)$ was higher in men $(5.2 \pm 1.2$ vs. $3.9 \pm 1.1)$. In adjusted analysis, IL-6 was positively associated with SU only in women; $p=0.018$ (Table 1). CRP was positively associated with SU in crude and adjusted analyses for both sexes; $p=0.002$ (Table 1). In addition, higher adiponectin was independently associated with lower concentrations of SU for men $(p<0.001)$ and women $(p=0.013)$ (Table 1).

Conclusion: The increase of SU is associated with IL-6 and CRP increasing and adiponectin decreasing since early adult age.

REFERENCES:

[1] Mortada I. Curr Hypertens Rep. 2017;19(9):69.

[2] Pouvreau C et al. J Inflamm Res. 2018;19(11):61-68.

Table 1. Mean SU concentrations ( $\mathrm{mg} / \mathrm{dL}$ ) according to physiological markers' tertiles

\begin{tabular}{|c|c|c|c|c|c|c|c|c|c|}
\hline \multirow{3}{*}{$\begin{array}{l}\text { Physiological } \\
\text { marker }\end{array}$} & \multirow[b]{3}{*}{ Tertile } & \multicolumn{4}{|c|}{ Men } & \multicolumn{4}{|c|}{ Women } \\
\hline & & \multicolumn{2}{|c|}{ Crude } & \multicolumn{2}{|c|}{ Adjusted } & \multicolumn{2}{|c|}{ Crude } & \multicolumn{2}{|c|}{ Adjusted } \\
\hline & & Mean & $\mathrm{Cl} 95 \%$ & Mean & $\mathrm{Cl} 95 \%$ & Mean & $\mathrm{Cl} 195 \%$ & Mean & Cl95\% \\
\hline & & & $p<0.001$ & & $p=0.12$ & & $p<0.001$ & & $p=0.018$ \\
\hline \multirow[t]{4}{*}{ IL-6 } & 1 & 5.01 & $\begin{array}{l}(4.91 \\
5.12)\end{array}$ & 5.16 & $\begin{array}{l}(5.06 \\
5.26)\end{array}$ & 3.67 & $\begin{array}{l}(3.58 \\
3.77)\end{array}$ & 3.85 & $\begin{array}{l}(3.76 ; \\
3.95)\end{array}$ \\
\hline & 2 & 5.29 & $\begin{array}{l}(5.19 \\
5.40)\end{array}$ & 5.30 & $\begin{array}{l}(5.19 \\
5.40)\end{array}$ & 3.81 & $\begin{array}{l}(3.72 \\
3.90)\end{array}$ & 3.88 & $\begin{array}{l}(3.79 \\
3.97)\end{array}$ \\
\hline & 3 & 5.46 & $\begin{array}{l}\text { (5.35; } \\
5.58)\end{array}$ & 5.30 & $\begin{array}{l}(5.18 \\
5.42)\end{array}$ & 4.23 & $\begin{array}{l}(4.14 ; \\
4.31)\end{array}$ & 4.03 & $\begin{array}{l}\text { (3.94; } \\
4.12)\end{array}$ \\
\hline & & & $p<0.001$ & & $p=0.002$ & & $p<0.001$ & & $p=0.002$ \\
\hline \multirow[t]{4}{*}{ CRP } & 1 & 5.01 & $\begin{array}{l}(4.93 \\
5.09)\end{array}$ & 5.14 & $\begin{array}{l}(5.05 \\
5.22)\end{array}$ & 3.57 & $\begin{array}{l}(3.47 \\
3.66)\end{array}$ & 3.77 & $\begin{array}{l}(3.67 \\
3.87)\end{array}$ \\
\hline & 2 & 5.37 & $\begin{array}{l}(5.26 \\
5.47)\end{array}$ & 5.31 & $\begin{array}{l}(5.20 \\
5.41)\end{array}$ & 3.89 & $\begin{array}{l}(3.80 \\
3.98)\end{array}$ & 3.95 & $\begin{array}{l}(3.86 \\
4.03)\end{array}$ \\
\hline & 3 & 5.62 & $\begin{array}{l}(5.48 \\
5.75)\end{array}$ & 5.42 & $\begin{array}{l}(5.28 \\
5.56)\end{array}$ & 4.13 & $\begin{array}{l}(4.06 \\
4.20)\end{array}$ & 3.99 & $\begin{array}{l}(3.92 \\
4.06)\end{array}$ \\
\hline & & & $p<0.001$ & & $p<0.001$ & & $p<0.001$ & & $p=0.013$ \\
\hline \multirow[t]{3}{*}{ Adiponectin } & 1 & 5.45 & $\begin{array}{l}(5.37 \\
5.54)\end{array}$ & 5.36 & $\begin{array}{l}(5.27 \\
5.45)\end{array}$ & 4.26 & $\begin{array}{l}(4.16 \\
4.36)\end{array}$ & 4.06 & $\begin{array}{l}(3.95 \\
4.16)\end{array}$ \\
\hline & 2 & 5.09 & $\begin{array}{l}(4.99 \\
5.20)\end{array}$ & 5.19 & $\begin{array}{l}(5.09 \\
5.30)\end{array}$ & 3.93 & $\begin{array}{l}(3.84 \\
4.01)\end{array}$ & 3.91 & $\begin{array}{l}(3.83 ; \\
3.99)\end{array}$ \\
\hline & 3 & 4.97 & $\begin{array}{l}(4.84 \\
5.09)\end{array}$ & 5.07 & $\begin{array}{l}(4.94 \\
5.19)\end{array}$ & 3.75 & $\begin{array}{l}(3.67 ; \\
3.82)\end{array}$ & 3.86 & $\begin{array}{l}(3.79 ; \\
3.93)\end{array}$ \\
\hline
\end{tabular}

Disclosure of Interests: None declared

DOI: 10.1136/annrheumdis-2021-eular.3790 